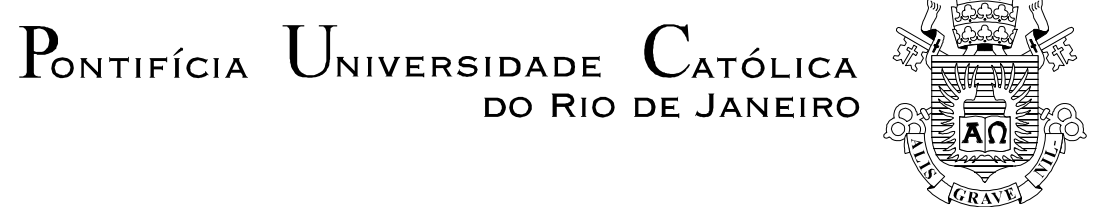

Tamara Moreira Vaz de Melo

Opressão e Resistência: As Duas Faces da Exceção

Dissertação de Mestrado

Dissertação apresentada ao Programa de PósGraduação em Direito da PUC-Rio como requisito parcial para obtenção do título de Mestre em Direito.

Orientador: Prof. José María Gómez 


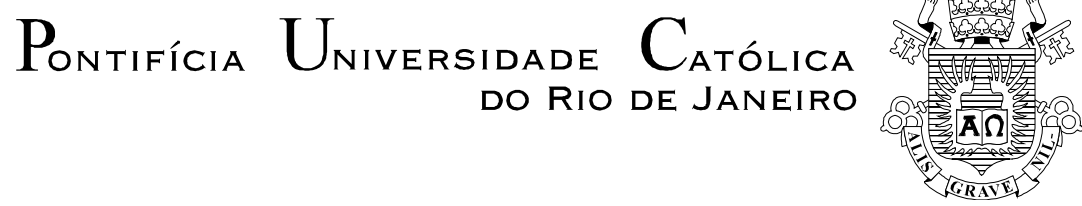

Tamara Moreira Vaz de Melo

\section{Opressão e Resistência: As Duas Faces da Exceção}

Dissertação apresentada ao Programa de PósGraduação em Direito da PUC-Rio como requisito parcial para obtenção do título de Mestre em Direito. Aprovada pela Comissão Examinadora abaixo assinada.

Prof. José María Gómez

Orientador

Departamento de Direito - PUC-Rio

Prof. João Ricardo Wanderley Dornelles

Departamento de Direito - PUC-Rio

Prof ${ }^{a}$. Bethânia de Albuquerque Assy Departamento de Direito - PUC-Rio

Profa. . Mônica Herz

Vice-Decana de Pós-Graduação do Centro de

Ciências Sociais - PUC-Rio

Rio de Janeiro, 18 de abril de 2012. 
Todos os direitos reservados. É proibida a reprodução total ou parcial do trabalho sem autorização da universidade, da autora e do orientador.

\section{Tamara Moreira Vaz de Melo}

Graduou-se em Direito pela Universidade do Estado do Rio de Janeiro (UERJ) em 2006. Cursou no mesmo ano Pós-Graduação em Direitos Humanos e Democracia pela Universidade de Coimbra (Portugal). É advogada da organização não-governamental Justiça Global, onde atualmente coordena um projeto de monitoramento do sistema carcerário brasileiro. Possui experiência na área de direitos humanos, com ênfase nos mecanismos internacionais de proteção da Organização das Nações Unidas (ONU) e da Organização dos Estados Americanos (OEA), atuando principalmente em temas relacionados com Violência Institucional e Segurança Pública.

Ficha Catalográfica

Vaz de Melo, Tamara Moreira

Opressão e resistência: as duas faces da exceção / Tamara Moreira Vaz de Melo; orientador: José María Gómez. - 2012.

$146 \mathrm{f.} ; 30 \mathrm{~cm}$

Dissertação (mestrado) - Pontifícia Universidade Católica do Rio de Janeiro, Departamento de Direito, 2012.

Inclui bibliografia

1. Direito - Teses. 2. Estado de exceção. 3. Direito. 4. Violência. 5. Opressão. 6. Resistência. 7. Política. I. Gómez, José María. II. Pontifícia Universidade Católica do Rio de Janeiro. Departamento de Direito. III. Título. 
Para Daniel, meu filho, com todo o meu amor. 


\section{Agradecimentos}

É muito importante registrar agradecimentos toda vez que se conclui uma etapa da vida. A elaboração desta dissertação se deu ao mesmo tempo em que descobria as alegrias e os desafios da maternidade. Meu filho Daniel nasceu durante o mestrado e, portanto, devo reconhecer que o seguimento desta pesquisa só foi possível graças ao apoio das pessoas queridas relacionadas a seguir.

Ao meu orientador, Professor José María Gómez, pelo estímulo e parceria incansáveis para a realização deste trabalho. Não tenho palavras para expressar toda minha admiração e gratidão.

À Coordenadora desta Pós-Graduação, Professora Gisele Cittadino, pela forma carinhosa e atenciosa com que sempre me recebeu em sua sala, pela compreensão das minhas dificuldades com prazos e pela confiança em mim depositada.

À CAPES e à PUC-Rio, pelos auxílios concedidos, sem os quais este trabalho não poderia ter sido realizado.

Ao meu marido Sergio, pela parceria de sempre, nos momentos bons e ruins, e a Daniel, minha dose diária de alegria, força e inspiração. Com vocês, meu mundo ganha cores lindas e suaves.

À minha mãe, Mônica, minha infinita gratidão. São tantas as razões para agradecer que não posso listá-las neste breve texto. Sem seu apoio, sua confiança e total disponibilidade não teria sido possível chegar até aqui. Obrigada por fazer deste meu sonho o seu também.

À minha irmã Natalia, minha grande amiga e cúmplice, e agora também madrinha de Daniel.

Ao meu pai, Marcos, à sua esposa Luciana e ao meu irmão Bernardo. Meus queridos, obrigada por todo apoio e pelo entendimento de tantos dias de ausência.

À tia Stella e a Luiz Henrique, por me receberem com enorme carinho e liberdade em sua casa, diariamente, para que pudesse estudar. Costumo dizer que tia Stella esteve presente nos dois partos da minha vida: no nascimento de meu filho Daniel, quando me acompanhou, como médica, dentro da sala de parto. E, depois, no "parto da dissertação", abrindo sua casa para que eu pudesse estudar todos os dias.

A D. Lourdes, pelos cafés de todas as tardes, que me ajudavam a recuperar as energias para dar seguimento ao estudo. 
Aos meus colegas da Justiça Global, grandes companheiros e companheiras da luta pelos direitos humanos, pela compreensão do meu afastamento temporário e, principalmente, por compartilharem comigo tantas inquietações que me impulsionaram a cursar este mestrado.

Às minhas amigas Ana Cristina, Carla, Joana, Juliana, Letícia e Manuela: as "Tamaretes", como ficou conhecido nosso grupo na época em que estudávamos no CAp. UFRJ. Amizades de infância e para sempre.

A Mariana Carvalho (Kakous), Mariana Cabral, Bruno Gabriel (Popys) e Maria Carolina, grande amigos da graduação, por acompanharem de perto, com carinho e estímulo, todo o meu caminho acadêmico e profissional.

Às amigas que conheci em Coimbra, principalmente, Cristiana, Daniela, Fernanda e Samantha, por compartilharem momentos maravilhosos e decisivos de nossas vidas.

Aos meus colegas da turma do mestrado da PUC-Rio, por tornarem essa experiência ainda mais interessante e rica. Um agradecimento especial a Carlos Eduardo Silva e Rafael Vieira, pelas preciosas trocas de informações, vivências, leituras, que contribuíram diretamente para esta pesquisa.

Aos professores integrantes da Comissão Examinadora, pela leitura atenta e pelas contribuições.

A todos os professores do Mestrado em Direito da PUC-Rio, pelos ensinamentos.

Aos funcionários, especialmente Anderson e Carmen, pelos incontáveis esclarecimentos e auxílios. 


\section{Resumo}

VAZ DE MELO, Tamara Moreira; GÓMEZ, José María. Opressão e Resistência: As Duas Faces da Exceção. Rio de Janeiro, 2012. 146p. Dissertação de Mestrado - Departamento de Direito, Pontifícia Universidade Católica do Rio de Janeiro.

O presente trabalho analisa o debate teórico e político sobre o estado de exceção com enfoque nas contribuições de Carl Schmitt, Walter Benjamin e Giorgio Agamben. Dessa maneira, busca examinar como a dinâmica das lutas sociais se insere nesta discussão. Os três autores, a partir de perspectivas muito diversas, entendem que o estado de exceção é imanente ao Estado de Direito e indicam a vida como o elemento que, na situação excepcional, encontra-se na relação mais íntima com a soberania. Portanto, a pesquisa parte do pressuposto de que não é possível reagir à exceção reafirmando a normalidade liberal que, em última instância, tem nela o próprio fundamento. Em seguida, observa que, para além da dimensão negativa do estado de exceção (como dispositivo de opressão), as discussões em torno do tema reconhecem o poder da resistência. Alguns procuram eliminá-la (como Schmitt); outros se esforçam para potencializá-la ao máximo, incitando a revolução (como Benjamin); e há ainda os que se dedicam prioritariamente a compreender o problema a fundo em vez de apontar os sujeitos e os meios concretos capazes de fazer frente a essa situação (como Agamben). Vale dizer, a exceção como regra é a opressão, mas o desafio que se coloca diante dessa realidade é trabalhar a resistência em face dela. Daí a necessidade de realizar o potencial subversivo que emana da própria situação excepcional denominado, neste estudo, dimensão positiva do estado de exceção. Para tanto, não se pode perder de vista a seletividade da exceção e entender que, por isso mesmo, a política parte do oprimido. Resta saber se o direito, apontado como instrumento de violência e dominação, deve ser negado em absoluto ou pode ser utilizado como uma gramática legitimadora das lutas. A conclusão deste trabalho é a de que, se o estado de exceção é um lugar estratégico das lutas políticas, o direito (o outro lado da mesma moeda) também o é. A ambigüidade da exceção atravessa o direito, e vice-versa. Há, em ambos, dimensões de opressão e de resistência.

\section{Palavras-chave}

Estado de Exceção; Direito; Violência; Opressão; Resistência; Política 


\section{Abstract}

VAZ DE MELO, Tamara Moreira; GÓMEZ, José María (Advisor). Oppression and Resistance: The Two Sides of Exception. Rio de Janeiro, 2012. 146p. MSc. Dissertation - Departamento de Direito, Pontifícia Universidade Católica do Rio de Janeiro.

This dissertation analyzes the theoretical and political debate about the state of exception with a focus on the contributions of Carl Schmitt, Walter Benjamin and Giorgio Agamben. Thus, it explores how the dynamics of social struggles fit in that discussion. From very different perspectives, the three authors understand that the state of exception is immanent to the rule of law, and reveals life as an element that, in exceptional circumstances, has a closer relationship with sovereignty. Therefore, this paper assumes that it is not possible to react to exception by reaffirming liberal normality, since that exception is ultimately within the very foundation of Liberalism. The paper then observes that, in addition to the negative dimension of the state of exception (as a tool of oppression), the debates concerning this issue acknowledge the power of resistance. Some seek to eliminate resistance (like Schmitt); others strive to empower it to the fullest, inciting revolution (as Benjamin). And there are those who devote themselves primarily to the task of deeply understanding the problem, instead of pointing out subjects and practical means able to cope with the situation (as Agamben). Notably, an exception is as oppressive as the rule; in the face of that reality, the challenge thus is to work on resistance. Hence, there is a need to make the subversive potential that emanates from very exceptional situationscalled, in this study, the positive dimension of the state of exception-real. To do so, one has to take into account the selectivity of an exception and understand that it is even because of that selectivity that politics come from the oppressed. The question is whether the law, appointed as an instrument of violence and domination, must be denied altogether or can be used as a tool to legitimate struggles. The conclusion of this work is that, if the state of exception is a strategic place of political struggles, the law (the flip side of that coin) is as well. The ambiguity of exception permeates the law and vice versa. They are in both the dimension of oppression and of resistance.

\section{Keywords}

State of Exception; Law; Violence; Oppression; Resistance; Politics 


\section{Sumário}

1. Introdução 11

1.1. Motivação 11

1.2. Breve Contexto: Liberalismo, Estado de Direito e Exceção 16

1.3. Tema, Hipótese e Objetivos 20

2. Exceção, Direito e Violência 23

2.1. Breve Apresentação do Debate Teórico 23

2.2. A Perspectiva dos Vencedores em Carl Schmitt 23

2.2.1. Exceção como prerrogativa do soberano 25

2.2.2. Amigo, inimigo e guerra 32

2.2.3. Nomos e exceção: situações constituintes do direito 35

2.3. O Olhar Sobre os Vencidos em Walter Benjamin 41

2.3.1. Exceção como Regra para os Oprimidos 41

2.3.2. Violência, Direito e Sacrifício da Vida Sacra 42

2.4. O Paradigma de Governo anunciado por Giorgio Agamben 48

2.4.1. Captura da Vida Nua pela Política 48

2.4.2. Estado de Exceção Permanente: O Novo Nomos da Terra 54

2.4.3. O Homo Sacer e o Bando Soberano 55

2.4.4. Campo: espaço puro e insuperável da exceção 58

3. Exceção: Lugar Estratégico das Lutas Sociais 62

3.1. Estado de Direito e Monopólio Decisório 64

3.2. Violência Pura 67

3.3. Verdadeiro Estado de Exceção 69

3.4. "Fechar a porta da lei" 73

3.5. Ação Verdadeiramente Política 76

4. Resistência Com ou Sem Direito 85

4.1. A Seletividade da Exceção e a Utopia da Liberdade 89

4.2. Campo: Símbolo da Política Moderna? 92

4.3. Espaços Emblemáticos da Exceção 98

4.4. Resistência Política (Interrupção do Campo) 107

4.5. O Direito Como Gramática Legitimadora das Lutas 112

5. Considerações Finais 134

$\begin{array}{ll}\text { 6. } & \text { Referências Bibliográficas } \\ & 138\end{array}$ 
O sábio grego, o profeta judeu e o legislador romano são sempre modelos que obsecam os que, hoje, têm como ocupação falar e escrever.

Michel Foucault 